in collaboration with his life-long friend Dr. (later Sir) B. C. A. Windle, he contributed several papers to scientific journals, of which one on "Man's Lost Incisors" and another on "Some Cranial and Dental Characters of the Domestic Dog" are particularly noteworthy. At the same time that he was thus engaged, he began to collect specimens to illustrate his lectures, succeeding to such an extent that he ultimately could claim to possess the most complete and valuable private odontological collection in Great Britain-a collection which with characteristic generosity he presented to the University on his retirement.

Although it is safe to say that this gift alone will serve to perpetuate his memory, Humphreys has many other claims for remembrance. By his survey of the glacial boulders in the Birmingham district, he has added appreciably to our knowledge of the ice-movements in that locality during the Pleistocene period, while by his presentation to the Birmingham Natural History Museum of a complete collection of the flora of east Worcestershire he has placed all lovers of that part of our countryside under a deep and permanent debt of gratitude. His work in these two directions was recognized by his election to the fellowships of the Geological and Linnean Societies.

In later years, Humphreys became more and more interested in antiquarian subjects, serving on the council of the Society of Antiquaries and acting as local secretary for Warwickshire and Worcestershire. He took an active and prominent part in the recent excavations at Uriconium and in the exploration of the Anglo-Saxon cemetery at Bidford-on-Avon, which latter was conducted with such care that it has been said "not a bead was lost". He traced, again with a wealth of topographical detail, the movements of the conspirators in the Gunpowder Plot on their dramatic flight from London to their last stand at Holbeach. He succeeded after a search, extending over three years, of the manor houses of the Midlands in finding in the butler's bedroom at Chastleton House near Moreton in Marsh several priceless Elizabethan Sheldon tapestries, two of which are now among the glories of the Victoria and Albert Museum and the Birmingham Art Gallery. Scarcely less dramatic was his discovery of the important "Bowery Papers" in a leather-covered wooden chest in a windowless attic at Cleeve Prior, where they had lain for more than two centuries. In 1924 the University of Birmingham, which had at various times conferred upon him the degrees of master of arts, doctor of philosophy and master of dental surgery, elected him to a readership in mediaeval archæology.

That Humphreys was able to accomplish so much, even granted his length of days, was due to exceptional ability and industry, and perhaps even more to tenacity of purpose. Great as these qualities are, it is for other and rarer qualities that his many friends will chiefly remember him-his wide sympathies, his unaffected friendliness, his complete disinterestedness. No one ever practised with greater persistence and success the gentle art of selfeffacement.

\section{Mr. J. H. Field}

THE scientific work of Mr. J. H. Field, whose death on May 19 at the age of sixty-four years is much deplored, was of a type none the less valuable because it was mainly practical rather than theoretical. He had qualified in physics and engineering at Cambridge and London, and was selected in 1904 for the Indian Meteorological Department to initiate upper-air work. He threw himself wholeheartedly into the task: regardless of hardships, such as those of the Northwest Desert in the hot weather, he adapted Western methods of getting data by kites and balloons to Indian conditions; the instrumental and mechanical equipments were largely designed and constructed by himself.

Financial difficulties were at first acute; but in 1912 matters improved and Field started the Agra observatory, which developed into a factory for making and compressing hydrogen, a workshop for making instruments, and a mother-station for a number of pilot-balloon observatories. In 1924 he took on the less congenial post of head of the Department; and for five years there he showed the enthusiasm and the tireless thoroughness that had always marked his activities. On his retirement he was responsible for a complete and able examination of the conditions that led to flying accidents in the lee of the Rock of Gibraltar.

Field's scientific papers consist mostly of data and discussions of the upper-wind system of India. $\mathrm{He}$ also carefully studied the exposure of thermometers at the ordinary observing stations. Perhaps his chief discoveries were the thinness of the monsoon currents in north-west India and the great increase of strength in the upper winds in the cold weather. He found also a marked tendency for an unusually vigorous increase to be followed by an unusually vigorous winter rainfall : here he always recognized that he had not data enough to justify reliable conclusions, but since his retirement this criterion has become the most reliable of the five criteria used in the winter forecast.

Field's real monument is the upper-air observing system of India, with about thirty-six observatories, and its well-designed equipment of instruments; but he secured also a new headquarters building at Poona. He will long be remembered by his staff for the inspiration of his indefatigable thoroughness and. for the justice of his rule.

G. T. W.

WE regret to announce the following deaths :

Prof. J. A. Culler, emeritus professor of physics in Miami University, Ohio, on May 18, aged seventynine years.

Sir Squire Sprigge, editor of the Lancet and author of "The Life and Times of Thomas Wakley" (1896), "Medicine: Its Practice and Public Relations" (1905), "Some Considerations of Medical Education" (1910) and "Physic and Fiction" (1921), on June 17, aged seventy-six years.

Prof. H. E. Slaught, emeritus professor of mathe. matics in the University of Chicago, on May 21, aged seventy-six years. 